\title{
Exploring the main threats to the threatened African spurred tortoise Centrochelys sulcata in the West African Sahel
}

\author{
Fabio Petrozzi, Edem A. Eniang, Godfrey C. Akani, Nioking Amadi \\ Emmanuel M. Hema, Tomas Diagne, Gabriel Hoinsoudé Segniageto \\ Laurent Chirio, Giovanni Amori and Luca Luiselli
}

\begin{abstract}
The African spurred tortoise Centrochelys sulcata is the second largest terrestrial turtle, with a scattered distribution across the West African Sahel. This species is threatened and declining consistently throughout its range, but little is known about the causes of its decline. It has been hypothesized that the decline is attributable to (1) competition with domestic cattle, (2) wildfire, and (3) the international pet trade. We conducted a series of analyses to investigate these three causes. Hypotheses 1 and 2 were analysed using a spatially explicit approach, using a database of the Food and Agriculture Organization of the United Nations and logistic regression modelling; hypothesis 3 was tested by analysing the CITES trade database for 1990-2010. We found a significant negative correlation between intensity of grazing (expressed as density of cattle, $\mathrm{km}^{-2}$ ) and the presence of spurred tortoises, and this negative effect increased when coupled with high fire intensity, whereas wildfires alone did not have a significant influence on the species' distribution at the global scale. There was a decrease in the annual export of wild individuals for the pet trade after the introduction of export quotas by country and by year, but trade data must be considered with caution.
\end{abstract}

Fabio Petrozzi* Godfrey C. Akani, Nioking Amadi and Luca Luiselli $\dagger$ (Corresponding author) Department of Applied and Environmental Biology, Rivers State University of Science and Technology, Port Harcourt, Nigeria E-mail 1.luiselli@ideccngo.org

Edem A. Eniang Department of Forestry and Natural Environmental Management, Faculty of Agriculture, University of Uyo, Akwa Ibom State, Nigeria

Emmanuel M. Hema Université Ouaga 1 Professeur Joseph Ki ZERBO/CUP-D, laboratoire de Biologie et Ecologie Animales, Ouagadougou, Burkina Faso

Tomas Diagne African Chelonian Institute, Ngaparou-Mbour, Senegal

Gabriel Hoinsoudé Segniagbeto Department of Zoology, Faculty of Sciences, University of Lomé, Togo

LAURent Chirio Grasse, France

Giovanni Amori National Research Council (CNR) Institute of Ecosystem Studies, Rome, Italy

${ }^{*}$ Also at: Ecologia Applicata Italia srl, Rome, Italy

†Also at: IDECC-Institute for Development, Ecology, Conservation and Cooperation, via G. Tomasi di Lampedusa 33, I-00144 Rome, Italy

Received 6 June 2016. Revision requested 4 July 2016.

Accepted 6 September 2016. First published online 23 January 2017.
Keywords CITES, conservation, pet trade, Sahel, spurred tortoise, tortoise-livestock competition, transhumant grazing system, wildfires

The supplementary material for this article can be found online at https://doi.org/10.1017/Soo30605316001125

\section{Introduction}

The African spurred tortoise Centrochelys sulcata 1 (Plate 1) is a native species of the Sahara Desert and the Sahel, where its distribution is fragmented (Trape et al., 2012; Petrozzi et al., 2015, 2016). All populations of this large tortoise (up to $90 \mathrm{~kg}$ weight) are reported to be declining, mainly as a result of two independent threats: competition with domestic livestock for food and space (Branch, 2008), and collection for the pet trade (CITES, 2006) and for subsistence (Branch, 2008). The species is categorized as Vulnerable on the IUCN Red List (Tortoise \& Freshwater Turtle Specialist Group, 1996).

The hypothesis that cattle are negatively affecting the tortoise's status and distribution had not been tested previously but is theoretically valid because of the characteristics of the Sahel ecosystem where the species occurs. The Sahel is a transitional ecoregion of semi-arid grasslands, savannahs and thorn shrublands across Burkina Faso, the Central African Republic, Chad, Eritrea, Ethiopia, Mali, Mauritania, Niger, Nigeria, Senegal and Sudan (Trape et al., 2012; Mallon et al., 2015). In the Sahel, which includes several of the world's economically poorest regions, most people rely on cattle grazing and derivate activities to survive (Touré et al., 1985; Barry et al., 1998; Kagoné, 2000). Two main types of grazing systems tend to coexist in countries of Sahelian Africa: traditional extensive systems and modern, semi-intensive to intensive ones (Kagoné, 2000). Traditional systems are low-input systems, with no supplemented food or chemicals being used except during emergency periods when forage availability is scarce. They include the transhumant Fulani system (c. 70\% of total cattle stock), sedentary village stock-raising, and stock rearing in developed pastoral areas. In the Fulani system, herds may be single-species (Sudanian Fulani zebu) or mixed, with small ruminants and cattle, and cattle are fed by opportunistic 


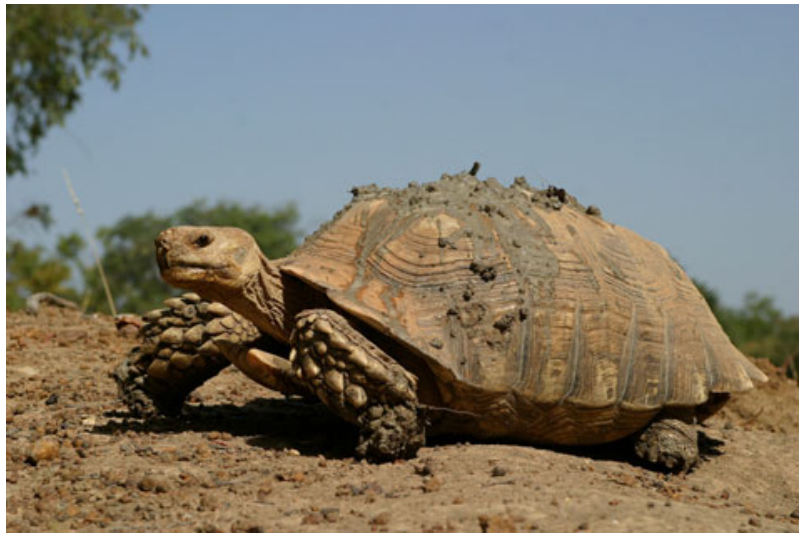

Plate 1 An adult Centrochelys sulcata in the 'W' National Park, Niger, West Africa. Photograph by B. Cornelis.

exploitation of forage resources according to a yearly sequence of grazing involving five seasons and the various types of pasture available (Barry et al., 1998; Kagoné, 200o). Both this system and modern intensive grazing are invasive for the natural vegetation of the Sahel and, as a consequence, large areas have been altered (Kagoné, 2000) and many species are threatened (Mallon et al., 2015).

Sahelian pastoralists burn wide areas to facilitate cattle grazing, and fires also spread naturally throughout the Sahelian region (Behnke, 1985; Smet \& Ward, 2005; Solomon et al., 2007). It is predicted that the spread of fires may have a negative effect on the distribution of spurred tortoises throughout the region.

The hypothesis that the international pet trade may be a factor in the depletion of spurred tortoise populations had not previously been analysed in depth, as it is difficult to test with field data. Nonetheless, CITES data are available and may provide some insight into potential conservation issues.

Our aims were (1) to explore the tortoise-livestock competition hypothesis by evaluating whether the distribution of spurred tortoises is negatively correlated with the density of domestic livestock, (2) to analyse whether there is an apparent effect of the spatial distribution of fires on the distribution of tortoises, and (3) to analyse the CITES database to identify general patterns in the international trade of Centrochelys sulcata.

\section{Methods}

Data sources and geographical information system (GIS) procedures

We extracted distribution data for spurred tortoises in West Africa from the literature (Trape et al., 2012; Petrozzi et al., 2015, 2016; Fig. 1a) and from original records collected by ourselves. Available data for Sudan, Ethiopia and Eritrea were poor and were not considered in the analysis, although spurred tortoises do occur in these countries (Largen \& Spawls, 2010).

From these data we deleted records of specimens that were not observed directly in the wild, as indicated in Petrozzi et al. (2015, 2016), or from areas where the species is now extinct (e.g. Cameroon; Chirio \& LeBreton, 2007). For each presence point we used the longitude and latitude graticule used by Trape et al. (2012), in which each grid cell was $11,449 \mathrm{~km}^{2}(107 \times 107 \mathrm{~km})$, in QGIS 2.12 .3 (QGIS Development Team, 2016). We deleted grid cells with $>50 \%$ of the area covered by sea, leaving 82 cells $(n=82)$.

Using QGIS we drew a minimum convex polygon inclusive of all presence points $(n=82)$. Within this we created 82 random absence points, using QGIS functions (Fig. 1b). When randomly selected absence grid cells coincided with presence cells the cells were replaced with new, random absence cells. Square grid cells (Trape et al., 2012) were used for both the presence and absence points.

Livestock density distribution data were extrapolated from Robinson et al. (2014). We clipped a raster of cattle density (Robinson et al., 2014) with a shape file covering the whole of the species' range, in which both presence and absence grid cells were included (Fig. 1c). We then reclassified the resulting raster file using the $\mathrm{FAO}$ format, with eight classes of density for livestock, yielding eight raster files. These were transformed into shape files, which were then merged into a single shape file. This was clipped for each presence and absence grid cell.

All the shape files (classified shape files, merged shape file, and presence and absence grid cells with cattle density) were processed using SpatiaLite v. 2.4.o (Furieri, 2015) to correct potential invalid geometries, thus obtaining an output file (.sql) for each grid cell. The .sql files were imported into QGIS and saved as a new shape file to obtain the surface of all the classes, both for each grid cell and in total. From the surface of each livestock class in each grid cell we calculated the percentage of cell territory covered by the various classes of livestock density. Eight classes of livestock density were used, as also used by FAO. Classes of predicted livestock density (expressed as number of animals per $\mathrm{km}^{2}$ ), as obtained from the FAO dataset $(\mathrm{FAO}, 2007)$ and used in our analyses, were: $0-1 ; 2-4 ; 5-10 ; 11-20 ; 21-50 ; 51-100$; 101-250; > 250 .

\section{Fire analysis}

The distribution of fire across the Sahelian region was calculated using historical MODIS (Moderate-resolution Imaging Spectroradiometer) data (NASA, 2015) for 2001-2015; fires detected covered at least $1,000 \mathrm{~m}^{2}$. A point shape file was clipped, as for cattle distribution, with each presence cell and each absence cell. In each cell, we determined the mean number of fires per day. 


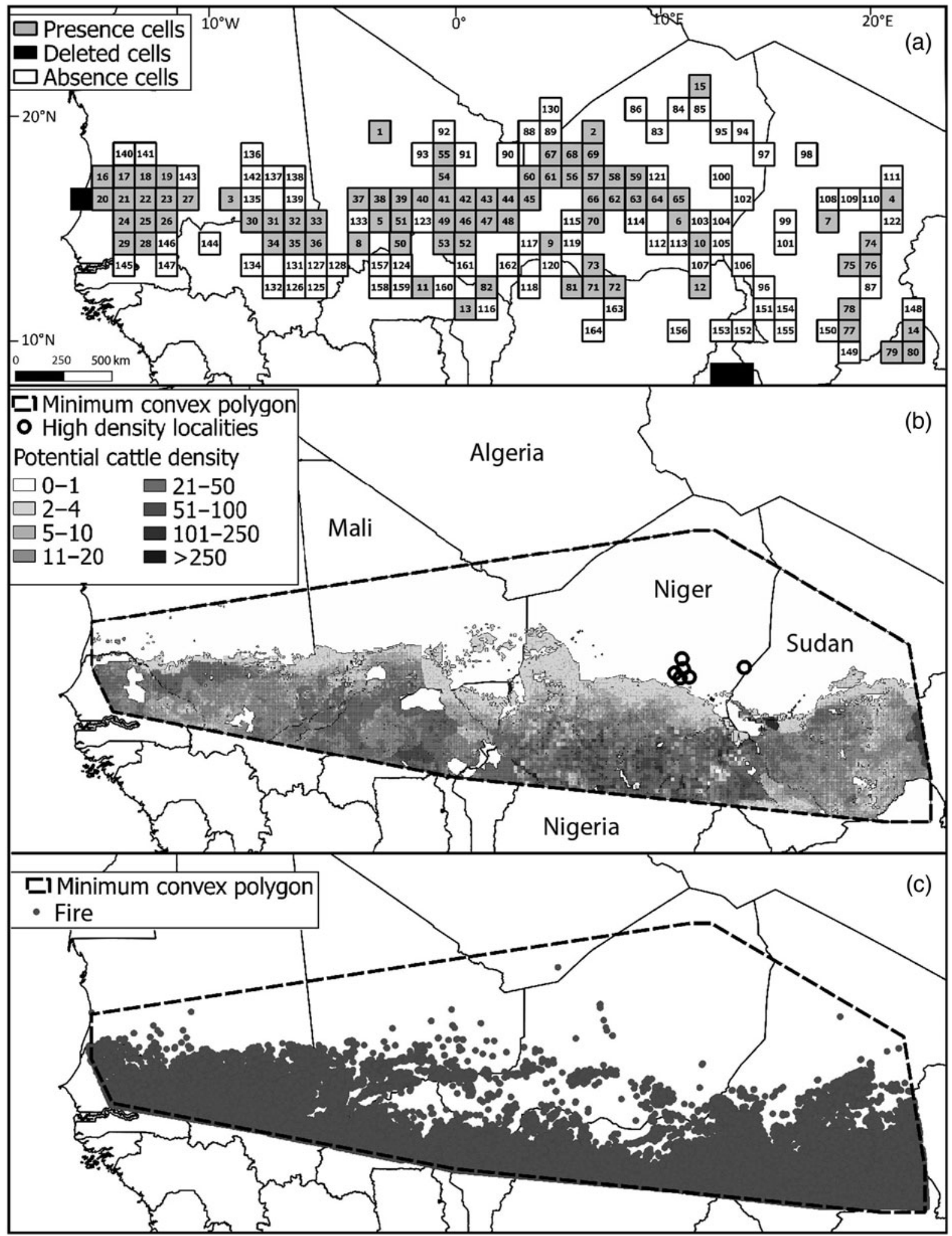

FIG. 1 Location of (a) presence and absence grid cells in a survey of the African spurred tortoise Centrochelys sulcata across the West African Sahel, with the reference numbers used in Table S1; (b) the potential distribution of cattle density, and the six sites with the highest recorded densities of spurred tortoises (white circles); and (c) the spatial distribution of fire intensity. Black grid cells in (a) were excluded from analyses. 
Trade analysis

We extracted all raw data available for spurred tortoises for the period 1990-2010 from the CITES trade database (CITES, 2015). Each record of import/export included the country of origin, whether the tortoise had been bred in captivity or taken in the wild, the purpose of the trade (e.g. commercial, scientific), and whether specimens were exported dead or alive, and whole or as parts (e.g. skins, shells, meat). It would be naive to assume that all species trade in the study area was legal, based on national quotas recorded in the CITES datasets. Many specimens are collected illegally in the countries of the Sahel and exported to Togo for the international pet trade (Auliya et al., 2016), and the species is also sought for the local pet trade (Petrozzi et al., 2016).

\section{Statistical analyses}

All statistical analyses were conducted using PASW 11.0 (IBM, Armonk, USA). For each presence and absence grid cell the proportionally dominant cattle density category (Supplementary Table $\mathrm{S} 1$ ) was used as a proxy for the overall effect of cattle on tortoises in the target grid cell; for example, if in a given grid cell the proportionally highest cattle density category was the fourth (i.e. $20>x \geq 10$ per $\mathrm{km}^{2}$ ), the value 4 was entered for that grid cell in the covariate variable of the logistic regression analysis. Presence/absence grid cells were then entered as dependent binary variables ( $o=$ absence of tortoises in a given grid cell; $1=$ presence of tortoises in a given grid cell) and their cattle densities as covariates in a logistic regression model. Although the predominant cattle density is a good indicator for a first analysis, with eight categories this dominant category may actually represent a tiny surface compared to the surface occupied by the other seven categories even if all of the seven occupy surfaces that are smaller than that of the predominant category. This introduces a bias. To prevent this we also calculated an indicator score by dividing the percentage of occurrence of the predominant category by the raw proportion of the surface it covers in the grid cell. This indicator score was then inserted into a logistic regression model in which the presence/absence of tortoises was the dependent variable. The higher the score, the higher the impact of grazing was, both in intensity and surface (per grid cell). For each presence and absence grid cell the fire intensity value was entered in a logistic regression model, as covariate, having verified that cattle density and fire intensity were not collinear in each cell $(\mathrm{P}>0.2)$.

We used the forward stepwise model, which adds the significant variables one-by-one to the model, starting with no variables (step o) and testing the addition of the variables of interest (cattle density and fire intensity) to improve the model. Differences in mean cattle density between presence and absence grid cells were analysed using a two-tailed student $t$-test, with $\alpha$ set at 5\%. One thousand bootstrap samples were calculated, and contrasted with real data. As inequality of variance was found in the dataset (Levene's test, $F=8.289, \mathrm{P}<0.005$ ), equality of variance was not assumed in the analysis.

For the trade analysis, the correlation between (log) number of traded individuals and year was examined using a polynomial model. The Akaike information criterion (AIC) for this relationship was calculated.

\section{Results}

\section{Tortoises and cattle}

The geographical distribution of presence sites in relation to the density of cattle across West Africa is shown in Fig. 1a,b. In general the density of cattle per grid cell tended to be higher in the southern part of the tortoise's distribution, in particular in the cells located in Nigeria and southern Burkina Faso (where classes 4, 5 and 6 were predominant), as well as in southern Mali (where classes 4 and 5 were predominant, with some small extensions of class 6). The grid cells in southern Senegal also showed a relatively broad extension of classes 4 and 5 . In Chad only one of the presence grid cells showed a broad extension of classes 4 and 5. The northern part of the tortoise's distribution was characterized by a concomitant low cattle density (classes 1, 2 and, in small part, 3 ).

Mean cattle density, expressed in terms of the dominant cattle density category in a given grid cell, was significantly higher ( $t$-test: $\mathrm{P}<0.027)$ in absence grid cells $(x=2.56 \pm \mathrm{SD}$ $1.69, \mathrm{n}=82)$ than in presence cells $(x=2.0 \pm 1.47, \mathrm{n}=82)$. At the six sites where our surveys found higher densities of spurred tortoises (authors, unpubl. data) the corresponding cattle density values were always o-1 individuals per $\mathrm{km}^{2}$ (Fig. 1b).

In our logistic regression $50.0 \%$ of cases were classified correctly (i.e. assigned correctly as random or used basking sites) at step o (i.e. no variables in the model, and before adding the variable cattle density, which improved the model) and 70.4\% of cases at step 1 (i.e. after the final model was assessed by adding the variable cattle density, which significantly increased the model fitting). Overall, the model was statistically significant $(B=-0.223, \mathrm{SE}=0.101, \operatorname{Exp}(\mathrm{B})=0.800, \mathrm{Wald}=4.812, \mathrm{df}=1$, $\mathrm{P}=0.028)$.

\section{Tortoises and fires}

The spatial distribution of fire intensity is presented in Fig. 1c. Our logistic regression model showed that $22 \%$ of cases were classified correctly (i.e. assigned correctly as random or used basking sites) at step o (i.e. no variables in the model, and before adding the variable cattle density, which improved the model) and $87.8 \%$ of cases at step 1 (i.e. after 


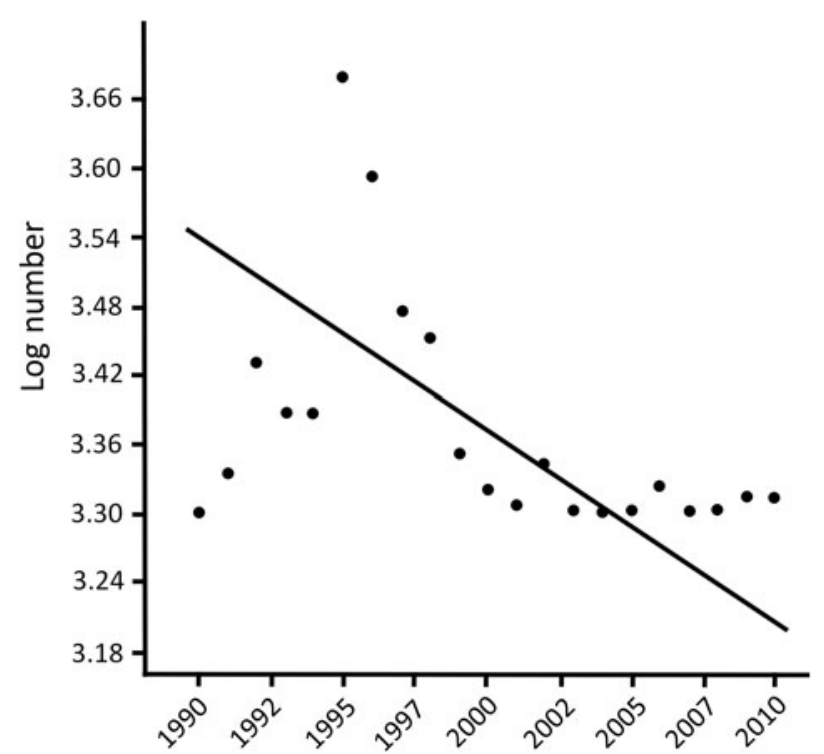

FIG. 2 Relationship between log number of traded individuals of Centrochelys sulcata and year (1990-2010). Data are from the CITES trade database (CITES, 2015).

the final model was assessed by adding the fire intensity variable and then the cattle density $\times$ fire intensity interaction variable, which significantly increased the model fitting). Overall, fire intensity alone did not influence the model significantly $(B=0.069, \mathrm{SE}=0.166, \operatorname{Exp}(\mathrm{B})=1.072$, Wald $=1.174, \mathrm{df}=1, \mathrm{P}=0.279$ ), whereas the cattle density $\times$ fire intensity interaction variable was statistically significant (Wald $=5.816, \mathrm{P}=0.012$ ). When the indicator score of livestock density was entered in the logistic regression model it was found that higher values of the score had a significant influence on the absence of the species, thus confirming patterns explained above $(\mathrm{B}=-0.341, \mathrm{SE}=0.084, \operatorname{Exp}(\mathrm{B})=0.711$, Wald $=16.662, \mathrm{df}=1, \mathrm{P}<0.001$ ).

\section{Tortoises and international trade}

According to the CITES database 2-2,790 spurred tortoises were traded annually during 1990-2010. In total, 9,132 wild individuals were traded during this period (yearly $x=434.9 \pm \mathrm{SD}$ 716.5). There was a negative polynomial correlation between year and $(\log )$ number of traded individuals $\left(r^{2}=0.600, \mathrm{n}=21\right.$, $\mathrm{P}<0.010 ; y=-0.034 x^{5}-1.371 x^{3}+2.741 x+1.095 ; \mathrm{AIC}=4.101$; Fig. 2). However, the relationship was clearly heteroscedastic, with less variation in more recent years.

A considerable portion of specimens $(33.6 \%)$ came from countries where the species does not occur (e.g. Togo, $\mathrm{n}=550$; Ghana, $n=1,713$ ) or where it is extinct (Cameroon, $n=235$; Chirio \& LeBreton, 2007). Thus, we may conclude that for many of the individuals traded as wild, the true country of origin is unknown. It appears that specimens traded from Togo originate in Burkina Faso, Niger and Mali (Petrozzi et al., 2016).

According to the CITES (2015) database 6,722 individuals ( $73.6 \%$ of the total traded) were reported to be wild but without indication of the country of origin (the country of export is reported). Ghana, Togo, Benin, Mali and Sudan were the main countries of export reported for the species.

The number of wild individuals traded decreased significantly from 2000 (when export quotas were introduced), from a mean of $859.1 \pm$ SD 868.6 per year during $1990-$ 1999 to a mean of $49.2 \pm$ SD 62.8 per year during 20002010 (Mann-Whitney $U$-test, $z=-3.346, \mathrm{P}<0.001$ ). A heterogeneity of slopes test showed that the slopes of the regression lines of number of exported individuals vs year were negative for wild individuals of known and unknown origin, and were significantly different between wild individuals of known origin and wild individuals of unknown origin (oneway ANCOVA: $F=232.5, \mathrm{df}=1,39, \mathrm{P}<0.05)$.

\section{Discussion}

\section{Spurred tortoises, cattle density and fire intensity}

The cell size in our grid of tortoise distribution $(107 \times 107 \mathrm{~km})$ is larger than ideal. For this type of study an ideal grid cell size would have been $10 \times 10 \mathrm{~km}$, as is typically used in modern atlases of vertebrate distribution. However, we were limited to the larger grid cell size because this was the size used for tortoise presence records in Trape et al. (2012). Our results should therefore be interpreted with some caution.

Our study provided correlational evidence that livestock density affects the presence of spurred tortoises throughout their range in the West African Sahel. This was shown by two kinds of analyses (a statistical test of the differences in mean livestock density between areas where tortoises are present and absent, and a logistic regression model in which the addition of the cattle density variable significantly enhanced the fit of a model of tortoise distribution, with a high density of cattle significantly depressing the probability of presence of the spurred tortoise). As the analysis was performed at the global scale of the tortoise's range, and surveys were probably more intensive in the more accessible areas of this logistically problematic and socio-politically unsafe region (i.e. in areas where livestock density may have been higher), the negative correlation between cattle density and spurred tortoise presence is likely to be correct. Circumstantial evidence has shown that the few sites where spurred tortoises are still abundant are characterized by a total absence of domestic cattle (e.g. in the ' $W$ ' National Park and the Termit Massif Total Reserve in Niger, where there is no livestock grazing pressure, LC encountered c. 10 tortoises per day).

The low density of spurred tortoises in areas where livestock are present may be a direct result of interspecific competition for food and habitat but may also be a result of hunting by livestock rearers. The tortoises are eaten by people throughout most of the Sahel, including in Burkina Faso 
(Petrozzi et al., 2016), the Central African Republic, Mali and Niger (LC, pers. obs.). Contemporary grazing patterns necessitate continual bush burning by livestock rearers (Behnke, 1985; Smet \& Ward, 2005; Solomon et al., 2007), and wildfire is known to be a threat to free-ranging populations of tortoises elsewhere (e.g. Hailey, 200o; Esque et al., 2002; Bertolero et al., 2011; Santos \& Cheylan, 2013) because of its indirect effects on desert habitats, which can result in changes in dietary composition and loss of vegetation cover, an increase in predation and loss of protection from temperature extremes (Esque et al., 2003). Our logistic regression modelling showed that fire intensity decreased the probability of finding a tortoise population within a given grid cell even more than the density of cattle alone, although fire intensity alone did not determine the presence/absence of tortoises within a given grid cell. Future studies should verify experimentally the competitive mechanism between spurred tortoises and domestic livestock, to guide more precisely the conservation management actions for this threatened species while minimizing negative impacts on impoverished human populations throughout the Sahel region. Where cattle are present, people are too, and they may eat tortoise meat (Petrozzi et al., 2016). Thus, grazing may not be the only cause of the tortoise's decline, and other factors are also relevant (e.g. habitat loss, wild and humanmade fires, hunting, and competition with livestock).

\section{Spurred tortoises and the international pet trade}

Data on the potential threat to the spurred tortoise from the international pet trade are incomplete. In particular, the significant variation in the number of tortoises traded legally each year suggests that the CITES database failed to record all the tortoises exported from the study region.

It appears that the number of wild individuals traded has been decreasing over the years and that the number of wild individuals for which the country of origin is unknown is now approaching zero. The number of wild individuals traded during 1990-2010 is remarkable for a large K-selected species with delayed sexual maturity (Branch, 2008). The reduction in yearly exports is probably attributable to multiple causes, including the establishment of export quotas by country and by year, and possibly the reduced number of individuals remaining in the wild. Experienced reptile dealers in Lomé, Togo, who usually trade the tortoises with Europe or the USA, reported to us that it is increasingly difficult to obtain the species from local hunters because it is considerably rarer than in the recent past in the traditional places of capture in Burkina Faso, Mali and Niger (G.H. Segniagbeto \& L. Luiselli, unpubl. data). The spurred tortoise is now apparently rare in nearly all sites where it is known to occur (e.g. Petrozzi et al., 2015, 2016), apart from a few remote semi-desert areas of Niger and Mali (L. Chirio, unpubl. data).
Mali appears to have experienced the highest losses to the pet trade, with specimens exported by Ghana, Niger, Togo and even Hungary and the USA declared to be of wild origin in Mali (a total of 1,313 tortoises in 1996 and 570 in 1997; CITES, 2006). The decline of the species in Mali was therefore predictable (Lambert, 1993), and new population surveys are needed urgently.

As the species has a scattered distribution (e.g. Diagne, 1995; Arvy et al., 1997), and most specimens originate from single collection localities (G.H. Segniagbeto \& L. Luiselli, unpubl. data), it is essential to collect data on population trends at exploitation sites in order to minimize the risk of further local extinctions (Chirio \& LeBreton, 2007). The majority of so-called wild specimens of Centrochelys sulcata traded during 1990-2010 were of unknown origin. This raises questions about the reliability of the CITES database and should be taken into consideration in future analyses of trade in spurred tortoises and other chelonians.

The putative impact of illegal trading in this tortoise species is considerable, as the trade of reptiles from north-west Africa is mostly illegal (and hence not recorded by the CITES database), facilitated by hyperporous geographical boundaries between countries and social instability. In some regions spurred tortoises are eaten regularly (Petrozzi et al., 2016), which could heighten the risk of extinction.

\section{Conclusions}

We analysed three factors that could be threatening wild populations of C. sulcata throughout its range: competition for food and space with domestic livestock (Branch, 2008), wildfire intensity, and the international pet trade (CITES, 2006). We found (1) a clear negative correlation between intensity of grazing (expressed as density of cattle per $\mathrm{km}^{2}$ ) and presence of spurred tortoises, (2) an increased detrimental effect of cattle density when coupled with high fire intensity, and (3) a consistent decrease in annual exports of wild individuals for the pet trade following the introduction of export quotas by country and by year, possibly because the trade moved partially from legality to illegality (i.e. given the increased difficulty in exporting wild individuals, such exports may now be hidden). Comparatively, domestic livestock appear to be a greater threat to the tortoise than fire or international trade, as there is no evidence that management of grazing has been better in recent years compared to the previous decades across the Sahel region. On the other hand, the number of wild individuals exported for the pet trade appears to be relatively low at present, although monitoring should continue. We recommend: (1) precautionary listing of the spurred tortoise on Appendix I of CITES, to prevent further exploitation of wild individuals for the international pet trade, as already suggested by the CITES authorities (CITES, 1994); (2) that more 
data be obtained to examine causal relationships, for example, by monitoring changes in cattle density in time and space on relevant temporal and spatial grids (monthly and $10 \times 10 \mathrm{~km}$, respectively); and (3) to improve the available data on the viability of spurred tortoise populations. We are planning to work jointly with governmental and non-governmental organizations and agencies to implement recommendations and follow-up initiatives based on the data presented here.

\section{Acknowledgements}

Some of the data were recorded during field surveys funded by the Mohamed Bin Zayed Species Conservation Fund (grant no. 13256954, to F. Petrozzi) and by the Turtle Conservation Fund (granted to F. Petrozzi). This article benefited from the critical comments of two anonymous referees.

\section{Author contributions}

FP and LL designed the study. FP conducted the GIS analyses. EAE, GCA, NA, EMH, TD, GHS and LC conducted the field surveys and collected presence data for the species. GA and LL conducted statistical analyses and drafted the article, and all authors read and revised the article.

\section{References}

Arvy, C., Marissal, N., Dia, A.T. \& Colas, F. (1997) Observations sur la répartition et les dimensions de Geochelone sulcata (Cryptodira, Testudinidae) en Mauritanie occidentale. Bulletin de la Société herpétologique de France, 81, 11-20.

Auliya, M., Altherr, S., Ariano-Sanchez, D., BaArd, E.H., Brown, C., Brown, R. et al. (2016) Trade in live reptiles, its impact on wild populations, and the role of the European market. Biological Conservation, 204, 103-119.

Barry, S., Illy, L., Kargougou, I., Kondé, M., Ouédraogo, S., PARKouda, S. et al. (1998) Etude sur la typologie des exploitations agricoles familiales et adoption d'une nouvelle stratégie agricole. Rapport définitif. FAO, Ouagadougou, Burkina Faso.

BeHnke, R.H. (1985) Open Range Management and Property Rights in Pastoral Africa. A Case of Spontaneous Range Enclosure in South Darfur, Sudan. Pastoral Development Network Paper. Overseas Development Institute, London, UK.

Bertolero, A., Cheylan, M., Hailey, A., Livoreil, B. \& Willemsen, R.E. (2011) Testudo hermanni (Gmelin 1789)Hermann's tortoise. In Conservation Biology of Freshwater Turtles and Tortoises: A Compilation Project of the IUCN/SSC Tortoise and Freshwater Turtle Specialist Group (eds A.G.J. Rhodin, P.C. H. Pritchard, P.P. van Dijk, R.A. Saumure, K.A. Buhlmann, J. B. Iverson \& R.A. Mittermeier), pp. 070.1-070.10. Chelonian Research Foundation, Lunenburg, USA.

Branch, B. (2008) Tortoises, Terrapins and Turtles of Africa. New Holland Publishing, Cape Town, South Africa.

Chirio, L. \& LeBreton, M. (2007) Atlas des reptiles du Cameroun. MNHN and IRD, Paris, France.

CITES (1994) Amendement aux annexes I et II de la CITES, Transfert de Geochelone sulcata de l'Annexe II à l'Annexe I; Proposition soumise au titer de la résolution Conf. 9. 24. Https://cites.org/fra/ cop/11/prop/38.pdf [accessed 27 November 2016].

CITES (2006) Consideration of Proposals for Amendment of Appendices I and II Prop. 11.38. Http://www.cites.org/eng/cop/11/ prop/38.pdf [accessed 25 November 2016].

CITES (2015) CITES Trade Database. Https:/trade.cites.org/ [accessed 27 November 2016].

Diagne, T. (1995) Etude et conservation de Geochelone sulcata au Sénégal. In Proceedings of the International Congress of Chelonian Conservation Proceedings, pp. 110-111. SOPTOM, Gonfaron, France.

Esque, T.C., Búrquez, A.M., Schwalbe, C.R., Van Devender, T.R., Anning, P.J. \& Nijhuis, M.J. (2002) Fire ecology of the Sonoran desert tortoise. In The Sonoran Desert Tortoise: Natural History, Biology and Conservation (ed. T.R. Van Devender), pp. 249-255. University of Arizona Press, Tucson, Arizona.

Esque, T.C., Schwalbe, C.R., Defalco, L.A., Duncan, R.B. \& Hughes, T.J. (2003) Effects of desert wildfires on desert tortoise (Gopherus agassizii) and other small vertebrates. The Southwestern Naturalist, 48, 103-111.

FaO (Food and Agriculture Organization of the United Nations) (2007) Gridded Livestock of the World 2007. FAO, Rome, Italy.

Furieri, A. (2015) SpatiaLite open source library. Https://www. gaia-gis.it/fossil/libspatialite/home [accessed 27 November 2016].

Hailey, A. (2000) The effects of fire and mechanical habitat destruction on survival of the tortoise Testudo hermanni in northern Greece. Biological Conservation, 92, 321-333.

KAGONÉ, H. (2000) Gestion durable des écosystèmes pâturés en zone nord-soudanienne du Burkina Faso. PhD thesis. Faculté Universitaire des Sciences agronomiques de Gembloux, Belgium.

LAMBERT, M.R.K. (1993) On growth, sexual dimorphism, and the general ecology of the African spurred tortoise, Geochelone sulcata, in Mali. Chelonian Conservation and Biology, 1, 37-46.

Largen, M.J. \& Spawls, S. (2010) The Amphibians and Reptiles of Ethiopia and Eritrea. Frankfurt Contributions to Natural History, Volume 38. Edition Chimaira, Frankfurt am Main, Germany.

Mallon, D.P., Hoffmann, M., McGowan, P.J.K. \& van Vliet, N. (2015) An IUCN situation analysis of terrestrial and freshwater fauna in West and Central Africa. IUCN, Gland, Switzerland.

NASA (2015) Fire Information for Resource Management System (FIRMS). Https://firms.modaps.eosdis.nasa.gov/download/ [accessed 23 May 2016].

Petrozzi, F., Hema, E.M., Luiselli, L. \& Guenda, W. (2016) A survey of the potential distribution of the threatened tortoise Centrochelys sulcata populations in Burkina Faso (West Africa). Tropical Ecology, 57, 709-716.

Petrozzi, F., Luiselli, L., Akani, G.C. \& Eniang, E.A. (2015) Supplementary distribution data of Centrochelys sulcata (Miller, 1779), in northern Nigeria (West Africa). Herpetozoa, 28, 92-94.

QGIS Development Team (2015) QGIS Geographic Information System. Open Source Geospatial Foundation Project. Http://www. qgis.org [accessed 27 November 2015].

Robinson, T.P., Wint, G.R.W., Conchedda, G., Van Boeckel, T. P., Ercoli, V., Palamara, E. et al. (2014) Mapping the global distribution of livestock. PLOS ONE 9(5): e96084. Dataset on cattle density available at: Http://www.fao.org/geonetwork/srv/en/main. search? extended $=$ off\&remote $=$ off\&any $=\mathrm{glw}+12713 \&$ themekey $=\&$ to $=\&$ from $=\&$ siteId $=\&$ hitsPerPage $=10$.

Santos, X. \& Cheylan, M. (2013) Taxonomic and functional response of a Mediterranean reptile assemblage to a repeated fire regime. Biological Conservation, 168, 90-98.

SMET, M. \& WARD, D. (2005) A comparison of the effects of different rangeland management systems on plant species composition, 
diversity and vegetation structure in a semi-arid savanna. African Journal of Range and Forage Science, 22, 59-71.

Solomon, T.B., Snyman, H.A. \& Smit, G.N. (2007) Cattlerangeland management practices and perceptions of pastoralists towards rangeland degradation in the Borana zone of southern Ethiopia. Journal of Environmental Management, 82, 481-494.

Tortoise \& Freshwater Turtle Specialist Group (1996) Centrochelys sulcata. The IUCN Red List of Threatened Species 1996: e.T163423A5605057. Http://dx.doi.org/10.2305/IUCN.UK.1996.RLTS. T163423A5605057.en [accessed 26 November 2016].

Touré, S.M., Ferrara, B., Lopez, G., Mattioli, R., Barbera, S. \& Disset, R. (1985) Etude générale de l'élevage au Burkina Faso. FAO, Ouagadougou, Burkina Faso.

Trape, J.F., Chirio, L. \& Trape, S. (2012) Lézards, crocodiles et tortues d'Afrique occidentale et du Sahara. IRD Editions, Paris, France.

\section{Biographical sketches}

Fabio Petrozzi works on the ecology and conservation of tortoises in the Sahelian region. Edem Eniang, Godfrey Akani and Nioking AmAdi work on the ecology and conservation of Nigerian reptiiles. EmmanUEL Hema works on the conservation of mammals and reptiles in Burkina Faso, Mali and Niger. Tomas Diagne specializes in the conservation of African chelonians. He is the president of the African Chelonian Institute (Dakar). GABRIEL Hoinsoudé SEgniagbeto works on the conservation ecology of reptiles in Togo and Ghana. LA URENT CHIRIO works on the distribution patterns of reptiles in Africa. Giovanni Amori works on the conservation and biology of mammals and reptiles in Africa and elsewhere. LuCA LUiseli works on the community ecology and conservation biology of West African vertebrates, particularly reptiles. 